\title{
Infodemic in Germany and Brazil
}

\section{How the AfD and Jair Bolsonaro are Sowing Distrust During the Corona Pandemic}

\author{
Dinah K. Leschzyk (D)
}

Accepted: 29 June 2021 / Published online: 9 August 2021

(C) The Author(s) 2021

\begin{abstract}
Even though the topic of infodemic - a blending of the words information and pandemic - emerged just in 2020 it addresses a question that has been crucial ever since in communication: How to establish - or undermine - credibility? This article deals with rhetorical techniques applied by Brazilian President Jair Messias Bolsonaro (2019-) and high-ranking politicians of the German party AfD (Alternative für Deutschland) during the COVID-19-pandemic. The analysis is based on tweets published through their official accounts during the first year of the pandemic (@jairbolsonaro, @AfD). Meanwhile Bolsonaro, who was in charge during the crisis, attacks the media claiming they would spread panic and false information, AfD, an opposition party, concentrates its criticism on the federal and state governments. The key concept credibility< as discussed by Ortwin Renn (2019) and basic claims that appear in Aristotle's »Rhetoric «, dating from the 4th century BC, build the theoretical basis of this study. Methodologically, the analysis is based on the Discourse-Historical Approach (Reisigl/Wodak 2001), focusing on discursive strategies of negative other representation, and a framework for studies on the language of legitimation and delegitimation developed by Theo van Leeuwen (1996).
\end{abstract}

Keywords Crisis Communication - Corona Communication · Bolsonaro - AfD · Right-Wing Populism · Infodemic · Disinformation · Discreditation · Credibility

Dinah K. Leschzyk $(\bowtie)$

Institute for Romance Studies, Justus Liebig University Giessen, Gießen, Germany

E-Mail: Dinah.K.Leschzyk@romanistik.uni-giessen.de 


\section{Infodemie in Deutschland und Brasilien}

Wie die AfD und Jair Bolsonaro in der Corona-Pandemie Misstrauen säen

Zusammenfassung In der sogenannten Infodemie - eine Wortmischung aus Information und Pandemie -, die 2020 aufkam, ist eine Frage zentral, die seit jeher grundlegend für die Kommunikation ist: Wie lässt sich Glaubwürdigkeit erzeugen bzw. untergraben? Gegenstand des vorliegenden Artikels ist die Rhetorik des brasilianischen Präsidenten Jair Messias Bolsonaro (2019-) sowie hochrangiger Politiker der deutschen Partei AfD (Alternative für Deutschland) im Rahmen der COVID-19Pandemie. Die Analyse basiert auf Tweets, die im ersten Jahr der Pandemie über die offiziellen Twitter-Accounts (@jairbolsonaro, @AfD) veröffentlicht wurden. Während Bolsonaro, der während der Krise amtierender Präsident ist, die Medien verbal attackiert und behauptet, diese würden Panik und Falschinformationen verbreiten, konzentriert sich die AfD, eine Oppositionspartei, mit ihrer Kritik auf die Regierungen von Bund und Ländern. Der Schlüsselbegriff Glaubwürdigkeit, definiert nach Ortwin Renn (2019), sowie Feststellungen, die bereits Aristoteles in seinem Werk Rhetorik (4. Jhd. v. Chr.) traf, bilden die theoretische Grundlage der Studie. Methodisch stützt sich die Analyse auf den Diskurshistorischen Ansatz (Reisigl/Wodak 2001), der u. a. auf diskursive Strategien der negativen Fremddarstellung abzielt, sowie ein von Theo van Leeuwen (1996) entwickeltes Schema zur Kategorisierung von Strategien der Legitimierung und Delegitimierung.

Schlüsselwörter Krisenkommunikation · Corona-Kommunikation · Bolsonaro · AfD · Rechtspopulismus · Infodemie · Desinformation · Diskreditierung · Glaubwürdigkeit

\section{Introduction}

The corona pandemic in 2020/21 came along with a special kind of information crisis that had never been seen before, where claiming to tell >the truth $<$, accusing the others to lie, deceive and sow panic was common. Rupali Jayant Limaye et al. (2020) observe: »Unlike historical pandemics [...], COVID-19 is spreading across a highly connected world, in which virtually all individuals are linked to each other through the mobile phone in their pockets. « For the phenomena in this context a new term has been created: infodemic. In a joined statement of WHO, UN, UNICEF, and other big international players on »Managing the COVID-19 infodemic: Promoting healthy behaviours and mitigating the harm from misinformation and disinformation« infodemic is defined as »an overabundance of information, both online and offline «, that »includes deliberate attempts to disseminate wrong information to undermine the public health response and advance alternative agendas of groups or individuals« (2020). As the international organizations outline:

Misinformation costs lives. Without the appropriate trust and correct information, diagnostic tests go unused, immunization campaigns [...] will not meet their targets, and the virus will continue to thrive. [D]isinformation is polariz- 
ing public debate [...]; amplifying hate speech; heightening the risk of conflict, violence and human rights violations; and threatening long-terms prospects for advancing democracy, human rights and social cohesion.

In an earlier statement the WHO (2020) links these misleading news, images, and videos with its wording directly to the pandemic, observing that »[1]ike the virus, it is highly contagious and grows exponentially. « The WHO Director-General at the time, Tedros Adhanom Ghebreyesus (2020), states: »We're not just battling the virus, we're also battling the trolls and conspiracy theorists that push misinformation and undermine the outbreak response.«

To this worldwide phenomena Germany and Brazil have been of no exception, even though the political and pandemic situation in both countries was - and is by now (June 2021) - completely different: Whereas in Brazil a far right populist president keeps downplaying the virus and its effects, the German government, led by long-term Chancellor Angela Merkel (Christian Democratic Union of Germany, $\mathrm{CDU}$ ), took the virus and it's risks absolutely serious right from the beginning, constantly implying measurements to »flatten the curve« of infections. It is a common place that times of crises are times of governments (see for example Decker/ Ruhose 2021, p. 1) as being in charge offers the possibility to handle the situation and therefore being perceived as the savior. The opposition on the other hand can either support the governmental decisions or criticize them - both strategies tend to have positive and negative implications and possible consequences for the actors. In Germany there was one party that started to criticize harshly on the government's actions almost right from the beginning of the pandemic, the so called Alternative für Deutschland, >Alternative for Germany< (AfD). This article focuses on a crucial claim of these statements, that is: This government cannot be trusted. In the Brazilian case, on the other side, the president attacks the trustworthiness of the media.

The main actors, Jair Bolsonaro and the AfD, will be presented in the following section (2.) together with the political and pandemic situation in Germany and Brazil. Questions concerning the credibility of actors are among the oldest in rhetoric theory as will be shown in section 3 . The key term credibility with its rather wide notion will be analyzed in the same section. The framework underlying the empirical analysis and the corpus will be described in section 4 . The findings of the analysis will be presented in section 5. In the last paragraph (6.) a resume and final considerations will be given. All tweets published by Bolsonaro and the AfD that are cited in this article are listed in the tables 4 and 5 in the appendix.

\section{The political and pandemic context in Brazil and Germany}

As early as February 2020 Frank Sieren, journalist of the Deutsche Welle, comments on the extraordinary speed with which misinformation and conspiracy theories ${ }^{1}$ are spreading in the coronavirus crisis (cf. Sieren 2020). This is especially true for Brazil, where the fact checking services had a tough time during the pandemic. Aos

\footnotetext{
1 For characteristics on conspiracy theories see Michael Butter (2018).
} 
Fatos for example checked the statements of Brazilian President Jair Bolsonaro on COVID-19 and found that during a period of six month (March to September 2020) more than 600 of his statements on the pandemic were false or distorted (cf. Ribeiro/ Cunha 2020).

Although Bolsonaro spent 30 years in politics, he positions himself as anti-establishment, hence following a fundamental populist principle (cf. Müller 2017, p. 26). In 1990 he was elected federal deputy for Rio de Janeiro and has not left the Chamber of Deputies until 2018, the year he was running for president (cf. Câmara dos Deputados 2019). He was elected in the second-round runoff and has been in the office since the $1^{\text {st }}$ of January 2019. Due to a limited airtime on television - amongst other reasons - he and his team have been using social media excessively during the presidential campaign. Vanice Maria Oliveira Sargentini and Geovana Chiari (2019, p. 459) observe: »Com pouco tempo de propaganda na televisão, Bolsonaro, a exemplo de D. Trump, aposta nos Tweets, em publicações de mensagens no Facebook e WhatsApp, centralizando, assim, seu canal de comunicação com os eleitores nas mídias digitais. $\aleph^{2}$ The nickname »Tropical Trump «, that media adopted straight from the beginning of his presidency (see for example the headlines of Xing (2019) and the Global Times (Editorial Board 2020)), seems very well earned, when comparing not only his social media use but also his statements on the media, women and minorities to the ones of former US-president Donald Trump. Due to his statements, actions and communication strategies Bolsonaro can be positioned as far right, fascist and populist. He disrespects the institutions, especially the Supreme Court (Pt. Supremo Tribunal Federal, STF), is pro-arms, anti-liberalization of abortion laws and against same-sex-marriage. Bolsonaro rejects the scientific consensus on climate change and is downplaying the corona pandemic (cf. Leschzyk 2020 pp. $107 \mathrm{f}$.) in which, so far (June 2021), more than 501.825 people have died in Brazil (cf. JHU 2021).

In terms of the pandemic the situation in Germany is far less dramatic than it is in Brazil. By now, June 2021, 90.400 people who have been diagnosed with an infection have died (cf. JHU 2021). The health care system is not about to collapse, so far everybody in need can be hospitalized. Anyways, the governments measurements to contain the pandemic have been criticized by the AfD continuously. The AfD was founded in 2013, a year that has been diagnosed a $»[p]$ erfect starting point for populists [...] « (Amann 2017, p. 17, translation D.L.) because of its overall climate of crisis. With reference to Frank Decker (2004) Fedor Ruhose (2020, p. 16) considers »political opportunity structures « (translation D.L.) a necessity for the successful creation of a populist party. The AfD was called a »Professor's Party « as some of its most prominent figures had been working at universities at some point in their life, including co-founder Bernd Lucke. Besides this curiosum, the party was highly mixed and ideologically without contours. The members were related by a »common rejection of the world « and a »negative community spirit« as Melanie Amann (2017, p. 56, translation D.L.) states. In 2015 the party had a »turn to the

\footnotetext{
2 Eng. > With little advertising time on television, Bolsonaro, following D. Trump's example, is betting on Tweets, Facebook and WhatsApp posts, thus centralizing his communication channel with voters in the digital media. This and all other translations are by the author and are as literal as possible.<.
} 
right «, that led to a right wing/far right party with a right-wing extremist part that is being monitored by the constitution protection service (Ger. Verfassungsschutz). The AfD was extremely successful in 2016, where »[t]he broad consensus among the parties represented in parliament [...] had created a vacuum « (Köcher 2016, p. 7, translation D.L.). Nowadays the party positions itself as anti-immigration, antiEuropean integration, pro >traditional $<$ gender roles and against same-sex marriage (cf. Alternative für Deutschland 2021). They criticize the established political parties, the media, and what they call >the elites $<$ in general. In election polls the voting intentions circulate between 9 and 15 percent (cf. IfD Allensbach 2021).

\section{The theoretical background}

When looking at the corona infodemic through a theoretical lens, a broad field opens. There are typical elements of populism, like criticism of the elites and the media; the claim to speak for >the people< as a homogeneous mass with one will, that only populists get to know; and a strong polarization in we vs. them that works with stigmatization, fear mongering and often hate speech (for a characterization of populism see for example Amann 2017; Jörke/Selk 2017; Mudde/Rovira Kaltwasser 2017; Müller 2017; Wodak 2015). As soon as the corona pandemic started, several studies on the communication during the crisis have been published. One to point out is More Than Words: Leaders' Speech and Risky Behavior during a Pandemic (2020) by Nicolás Ajzenman, Tiago Cavalcanti and Daniel Da Mata. The researchers' key finding is that Bolsonaro's supporters follow experts' advice less than his non-voters. They conclude:

We find that after Brazil's president publicly and emphatically dismisses the risks associated with the COVID-19 Pandemic and advises against isolation, social distancing measures of citizens in pro-government localities reduce relative to those places in which his support is weaker [...]. The impact is large and robust to different empirical model specifications (Ajzenman et al. 2020).

As mentioned before, two of the key words for corona infodemic are disinformation and misinformation; while disinformation can be defined as $\gg$ knowingly false content meant to deceive « (Brennen et al. 2020, p. 2), something that is difficult to prove, misinformation is used to »refer broadly to any type of false information including disinformation « (ibid.). ${ }^{3}$ The WHO et al.(2020) considers mis- and disinformation as possibly »harmful to people's physical and mental health«, due to the fact that it can »increase stigmatization; [...] and lead to poor observance of public health measures, thus reducing their effectiveness and endangering countries' ability to stop the pandemic. «

A salient feature of this infodemic is, that actors claim to tell >the truth<, to refer to >the facts<, while others would spread false information. If it is not possible to determine from one's own experience whether claims are correct, the question is,

\footnotetext{
3 A more detailed typologization of misinformation can be found in »Types, sources, and claims of COVID-19 misinformation« by Brennen et al. (2020).
} 
whose information is trustworthy. Therefore, credibility is a key concept (cf. Renn 2019 , p. 77). The concept has a rather wide notion. It can be narrowed down to basic definitions like: Credibility is »the fact that someone can be believed or trusted « (Cambridge Dictionary 2014); »[i]f someone or something has credibility, people believe in them and trust them « (Collins Dictionary n.d.); credibility is »the quality of deserving to be believed and trusted « (Longman Dictionary 2020). For Ortwin Renn (2019, pp. 77 f., translation D.L.), a person or institution is said to be credible »if the information we receive from them is true (in accordance with the facts) and truthful (not distorting its own intention) to the best of the sender's knowledge and belief «. ${ }^{4}$ Renn (2019, p. 77, translation D.L.), sociologist specialized in risk research, refers to credibility and trust as »sensitive resources«. Marlene Odenbach (2005, p. 194, translation D.L.) speaks of credibility in a similar way, describing it as a »highly sensitive, fragile asset « that, once damaged, only can be restored at great expense (time and money). And - if it can be restored at all - »glued [...] is just not as good as new « (ibid.).

Credibility is - together with reliability that is referred to as performance (cf. Williams 1985 as cited in Renn 2019, p. 78, translation D.L.) - a central component of trust. Trust means »granting a person or institution [...] that they are doing the right and sensible thing in each case, even if one cannot comprehend or verify the motives in detail« (Renn 2019, p. 78, translation D.L.). Performance in that sense means »that the respective institution properly fulfills its task in the sense of the given mission [...]« (Renn 2019, p. 78, translation D.L.). Both components can further be split up: »credibility [...] is tied to openness, transparency, and honesty; performance to competence, fairness, and commitment « (Renn 2019, p. 78 in reference to Renn/ Levine 1991, pp. 179 f., translation D.L.). Another key criterion for attributing trust is straightforwardness, which is tied to both components - credibility and performance (ibid.). These criteria for attributing trustworthiness are listed in the following table 1.

The fundamental loss of trust in the credibility of sources is accompanied by insecurity and cynicism. Renn (2019, p. 84, translation D.L.) speaks of »insecure to cynical people who have lost basic trust in groups and institutions of knowledge transfer and have only derision and contempt left for the seemingly public-spirited institutions. « Populists, for their part, »deliberately tap into the insecurity caused by

Table 1 Criteria for the attribution of trustworthiness (according to Renn 2019, pp. 78 f., translation D.L.)

\begin{tabular}{ll}
\hline Components of trust & Attributed criteria \\
& openness \\
transparency & honesty \\
credibility & straightforwardness \\
& competence \\
performance & fairness \\
& commitment \\
\hline
\end{tabular}

\footnotetext{
${ }^{4}$ I have applied and described the concept of trustworthiness by Renn (2019) more in detail in my article »Diskreditierung in der Krise. Rhetorische Angriffe auf die Vertrauenswürdigkeit der österreichischen Regierung« (in print).
} 
a lack of loyalty to conventional institutions such as science, politics, or authorities, promising security and safety if one would only confide in them « (Renn 2019, p. 84, citing Milbradt 2018, p. 206, translation D.L.). Keeping that in mind, one of the oldest questions of rhetorical studies emerges: How do actors establish their trustworthiness while undermining that of their opponents? These questions have already been addressed by Aristotle. In his magnum opus Rhetoric (II, 1378a [2015, p. 67]) dating from the 4th century BC, Aristotle comments on the question how to appear a credible person: »There are three things which inspire confidence in the orator's own characterhe three, namely, that induce us to believe a thing apart from any proof of it: good sense, good moral character, and goodwill.« There are obviously significant overlaps to the criteria of trustworthiness identified by Renn who uses the modern expressions competence, straightforwardness, fairness and so on (see table 1). As »the objects of praise and blame« Aristotle (I, 1366a [2015, p. 35]) considers »Virtue and Vice« and »the Noble and the Base«. When the philosopher talks about »forms of Virtue $(I, 1366 a$ [2015, p. 36]) he refers to »justice, courage, temperance, magnificence, magnanimity, liberality, gentleness, prudence, wisdom «. As effective rhetorical ways of blaming or praising a person Aristotle (I, 1368a [2015, pp. 40f.]) then mentions »heightening the effect « - as to say intensification -, comparison, and examples. These techniques will be kept into mind, when analyzing the communication of populist actors during the corona crisis. In the following section the data material of the analysis and the methodological approach will be introduced.

\section{The analytical framework and the corpus}

Beyond the classical Aristotelean approach presented in section 3. the analytical framework for the analysis of techniques for establishing - or undermining - trustworthiness involves discursive strategies of positive self- and negative other-presentation. This type of strategy - strategy is understood as »a more or less accurate and more or less intentional plan of practices (including discursive practices) adopted to achieve a particular social, political, psychological or linguistic aim « (Reisigl/Wodak 2001, p. 44) - is addressed by the Discourse-Historical Approach (DHA) as presented in $»$ Discourse and discrimination. Rhetorics of Racism and Antisemitism « (2001) by Martin Reisigl and Ruth Wodak. As Reisigl (2017, p. 92) points out, there are several linguistic techniques that can be used in the context of predicational strategies - an observation that also applies to the other strategies. Reisigl/ Wodak (2001, pp. 44f.) list key questions that can be helpful to identify these different strategies. As this analysis is focused on negative other-presentation, which is considered predominant in the discourse, meanwhile self-presentation plays a minor role, the strategies of nomination and predication are given special attention (see table 2). 
Table 2 Categories and key questions of the analysis (cf. Reisigl/Wodak 2001, pp. 44 f.; Renn 2019, pp. 78 f.; van Leeuwen 2013, pp. 327 f.)

\begin{tabular}{|c|c|}
\hline $\begin{array}{l}\text { Referential/ } \\
\text { Nomination strategies }\end{array}$ & How are actors named and referred to regarding the components of trust? \\
\hline Predicational strategies & $\begin{array}{l}\text { What characteristics are attributed to actors when it comes to their credibil- } \\
\text { ity and }\end{array}$ \\
\hline $\begin{array}{l}\text { (De-)legitimation } \\
\text { strategies }\end{array}$ & $\begin{array}{l}\text { Which categories (authorization, moral evaluation, rationalization, } \\
\text { mythopoesis) are addressed to (de-)legitimate claims? }\end{array}$ \\
\hline
\end{tabular}

The DHA is compatible with a framework for analyzing the language of legitimation and delegitimation by Theo van Leeuwen $(1996)^{5}$, strategies that also come into play when undermining credibility. Van Leeuwen (2013, p. 330) characterizes legitimation »as an answer to the spoken or unspoken $>$ why< question $->$ Why should we do this? or > Why should we do this in this way? « The analysis of these strategies concerns the question of what is referred to for making statements seem plausible (strategies of legitimation) or implausible (strategies of delegitimation). The focus here lies on strategies of delegitimation, as to say: By reference to what or whom do actors invalidate the statements of a) the government (AfD) and b) the media (Bolsonaro)?

Van Leeuwen (2013, pp. $327 \mathrm{f}$.) identifies four major categories of legitimation: authorization, moral evaluation, rationalization and mythopoesis (see table 2). As he shows, »one of the >forms and contents of legitimation< is, >because I say so<, where the $>\mathbf{I}<$ is someone in whom some kind of authority is vested, or $>$ because so-and-so says so<, where the authority is vested in >so-and-so « (van Leeuwen 2013, p. 330). Authority can be categorized into Personal Authority, Expert Authority, Role Model Authority, Impersonal Authority, The Authority of Tradition and The Authority of Conformity (cf. van Leeuwen 2013, pp. 330-334). Moral legitimation can further be differentiated into Evaluation, Abstraction and either positive or negative Comparison (cf. van Leeuwen 2013, pp. 334-337). As van Leeuwen (2013, p. 338) observes, »[i]n the case of moral evaluation, rationality has gone underground.« Meanwhile »in the case of rationalization, morality remains oblique and submerged, even though no rationalization can function as legitimation without it « (ibid.). (De-)Legitimation by rationalization can be distinguished in Instrumental Rationalization and Theoretical Rationalization (cf. van Leeuwen 2013, pp. 338-343): »Instrumental rationality legitimates practices by reference to their goals, uses and effects. Theoretical rationality legitimates practices by reference to a natural order of things [...] « (van Leeuwen 2013, p. 338). The fourth category of (de-)legitimation concerns storytelling as in moral tales and cautionary tales (cf. van Leeuwen 2013, p. 343).

As pointed out before, Bolsonaro is being called »Tropical Trump« and like his US-role model he uses social media excessively. This calls out for the analysis of texts that have been published through this type of media. For this study I have built

\footnotetext{
5 Van Leeuwen has described the categories for the first time in the unpublished manuscript »The Grammar of Legitimation « (School of Media, London College of Printing). They are presented in van Leeuwen/ Wodak (1999, pp. 104f.) and van Leeuwen (2013) among others.
} 
Table 3 The data material (31.01.2020-28.02.2021)

\begin{tabular}{lllll}
\hline Username & $\begin{array}{l}\text { number } \\
\text { (re-)tweets }\end{array}$ & corona discourse & corona* & covid* $^{*}$ \\
@AfD & 2727 & 576 & 346 & 56 \\
@jairbolsonaro & 2859 & 561 & 79 & 193 \\
\hline
\end{tabular}

a corpus of tweets that have been published on his official account @jairbolsonaro throughout the first year of the pandemic (2020). The first time that the word corona has been used by Bolsonaro in a tweet was the $31^{\text {st }}$ of January 2020 . That sets the starting date for the data collection that ended the $28^{\text {th }}$ of February 2021. In total corona appears 79 times in Bolsonaro's tweets and retweets, meanwhile the term covid is used 193 times.

It is interesting that in the German context it is the AfD that is dominating the field of social media in comparison to the other political parties. On @ AfD, the party's official account on Twitter, the first tweet on the corona pandemic is published almost the same day as on Bolsonaro's account: the $1^{\text {st }}$ of February 2020. Even the total number of (re-)tweets on the two accounts is similar with 2727 published through @ AfD and 2859 on the channel @jairbolsonaro. The same applies to the number of (re-)tweets that belong directly to the corona discourse: 576 (@AfD) and 561 (@jairbolsonaro). Unlike Bolsonaro the AfD uses the term corona more frequently than the word covid (see table 3 for these stats). Besides similarities in quantity, it is to be expected that there will be used similar statements and arguments by both political actors. As there are strong ties between far-right positions all around the world the same discursive strategies, rhetorical techniques, and keywords are used in settings that are as different as Brazil and Germany.

The analysis software MAXQDA Analytics Pro (version 2018.2) was used to process the data material. It is a paid software of the company VERBI, by means of which qualitative and quantitative data analyses can be supported. It enables automated searches and allows, for example, to determine the quantities of single terms and collocations.

\section{Undermining trustworthiness in the corona pandemic 2020/21}

This section addresses the questions of how the AfD affronts the government's trustworthiness and how Bolsonaro attacks the trustworthiness of the media during the COVID-19-pandemic. The concept of trustworthiness is operationalized by using Renn's (2019, p. $87 \mathrm{f}$.) criteria bearing in mind that already Aristotle mentions good sense as to say expertise, character and goodwill as fundamental aspects of how to appear a credible person (see section 3.). All posts excerpted in this paper are listed in the appendix with their respective URLs (tables 4 and 5).

\subsection{AfD's attacks on the trustworthiness of the government}

In the AfD's corona discourse on Twitter (576 tweets and retweets on @ AfD) the German Chancellor Angela Merkel is addressed 66 times directly by her name, of 
which 41 times a hashtag is being set (\#Merkel). Her first name is used four times and there are four references to her political office (Bundeskanzlerin, Kanzlerin). Merkel is attributed as >arrogant $<$, >ideologically stubborn $<$, acting without considering the facts (>fact-free $<$ ) and - in general - lacking leadership ( $>$ not leading, only reacting $<) .{ }^{6}$ These are predications that have a negative impact on the performance of any politician and therefore are suitable to diminish the trustworthiness of the Chancellor. The drastic demand Merkel must go is used twice (tweets 24, 37). In a retweet from Stephan Brandner (@StBrandner), member of the Bundestag (German federal parliament), whose radical rhetoric in the corona discourse is particularly striking, Merkel is referred to as millionenfache Verfassungsbrecherin (Eng. >million times Constitution breaker $<)^{7}$, who should be $>$ locked up $<$ together with $>$ her accomplices $<-$ a term (Ger. Helfershelfer) that is often used in the context of the Holocaust:

\section{(1) RT @ StBrandner: Meine Rede: Die millionenfache Verfassungsbrecherin}

\section{\#Merkel und ihre Helfershelfer einsperren! (tweet 26).}

The topos of illegitimacy is addressed frequently in AfD's corona discourse when it comes to discredit the government. The (de-)legitimation strategy therefore is reference by authorization: The Constitution says so and so (type: >impersonal authority $<$ ). That the government's crisis management would not match democratic principles at all is expressed by the term Diktatur (Eng. >dictatorship<) (see tweet 28), that is used in the rhetoric of AfD's politicians frequently (ten times in the overall data material, three more times as adjective: diktatorisch). This reference follows the strategy of moral delegitimation by a negative comparison of the government's crisis management to a form of government characterized by no toleration for freedom of expression, equality, consent, voting and other democratic values. The same strategy applies when Merkel is being accused of having an >anti-democratic attitude< (tweet 40). Besides the claim of a \#Corona-Diktatur the AfD creates the term \#Coron-

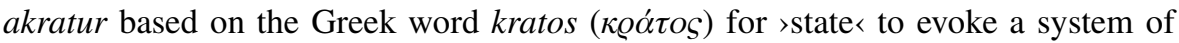
government where corona is the power source and in which >all prime ministers dance to Merkel's tune< - an attack on the prime ministers' >straightforwardness < a central component of trustworthiness:

(2) RT @StBrandner: \#5Fragen5Antworten [...]: \#Coronakratur bis in alle \#Ewigkeit? Wird es jemals ein \#Lockdownende geben? Wieso tanzen alle \#Ministerpräsidenten nach \#Merkells Pfeife? (tweet 1).

Suggestive questions as seen in example 2 are used on a regular basis in tweets published through@AfD. This rhetorical technique insinuates that the sender is stating the obvious, meanwhile an allegation - that is not questioned - is made.

Furthermore, the topos of illegitimacy is addressed by Alice Weidel, leader of the AfD in the Bundestag, who claims that >Merkel turns violation of the law into a political principle< (tweet 32). She combines this allegation in the following tweet

\footnotetext{
6 See tweets $39,34,34$ and 42 .

7 All translations of AfD's tweets are mine. The complete German wording can be found in the appendix (table 4), followed by the corresponding Twitter-ID.
} 
with an attack on the overall competence of the grand coalition (Große Koalition, often abbreviated as $\mathrm{GroKo})^{8}$ by the word Totalversagen (>total failure<):

(3) RT @ Alice_Weidel: Merkel macht Rechtsbruch zum politischen Prinzip! Die \#GroKo glänzt durch Totalversagen. Von Wirtschaft über Klima und Justiz bis hin zu Flüchtlingspolitik und \#Corona-Wahn - alles haben \#Merkel und ihre Regierung in den Sand gesetzt. Meine Generalabrechnung seht Ihr im Video: https://t.co/CKTKcvgd4W (tweet 32)

The supposed $>$ failure $<$ is part of a fundamental critique of the government's >performance< during the corona crisis and another topos that is frequently referred to by the AfD. The term versagen (Eng. >failure $<$ ) is used six times in the tweets and retweets, one more time with reference to the federal government (\#Regierungsversagen), two times referring explicitly to Merkel and the topic vaccinations (\#Merkel ihr \#Impf-Versagen; sie wegen des Impf-Versagens), another time implicitly to the government and other parties that are called \#Altparteien ${ }^{9}$ in the rhetoric of AfD's politicians (\#Politik-Versagen) and one time to the government of the state Thuringia (Versagen der Landesregierung). ${ }^{10}$

The attribution >crazy< evoked by the word Wahn as in \#Corona-Wahn (see example 3), downgrades the government's trustworthiness even further, regarding its straightforwardness. ${ }^{11}$ The strategy of (de-)legitimation applied is reference by rationalization as someone who is crazy does not act rational at all and therefore cannot be trusted to manage a pandemic accordingly. The lexeme Wahn is used ten times in the corpus, two times with explicit reference to Merkel (Merkels Coronawahnsinn, Merkels \#Coronawahnsinn, tweets 21 and 18), one time with reference to the government and one time referring to Markus Söder, Minister-President of Bavaria (Christian Social Union in Bavaria, CSU) in another way, >megalomania< (\#Söder s Größenwahn), that is still affecting the politician's trustworthiness (tweet 2). In another tweet it is claimed, that Söder >is going crazy<(durchdrehen) (tweet 11), a verb that is also used with reference to Armin Laschet, Minister-President of the state of North Rhine-Westphalia (tweet 30). The supposed >insanity< of the governing politicians is addressed furthermore by the terms Irrsinn (Eng. >insanity<), as in Lockdown-Irrsinn (tweet 24), and Hysterie (Eng. >hysteria<) used three times as a hashtag: \#Corona-Hysterie (tweets 27, 29) and \#Corona-\#Hysterie (tweet 36).

The topos of failure is addressed by a broad variety of expressions ranging from objective ones like Fehlentscheidungen as in folgenreichen Fehlentscheidungen der Bundesregierung (Eng. >consequential wrong decisions of the federal government $<$ ), tweet 35, to colloquial ones used for personal attacks as in \#Merkel taugt nichts, von

\footnotetext{
8 The Große Koalition is a coalition of the parties CDU/CSU and SPD (Social Democratic Party of Germany).

9 As it is common in right wing populism, the AfD positions itself as anti-establishment, calling the established parties >old parties $<$ in a derogatory way.

10 See tweets 7, 3, 5, 6 and 10 in the appendix.

11 Even more explicit in a tweeted quote of Sebastian Münzenmaier, member of the Bundestag: Verrückt gewordene Politiker spielen sich als Corona-Sheriffs auf! (Eng. >Politicians gone mad act as Corona sheriffs $<$, tweet 8).
} 
der Leyen ${ }^{12}$ noch weniger (Eng. >\#Merkel is no good, von der Leyen even less $<$ ) (tweet 43). The extreme expression Desaster (Eng. >disaster $<$ ) is used four times to describe the government's crisis management and its consequences for the \#Steuerzahler (Eng. >taxpayer $<$ ) and Bürger und Wirtschaft (Eng. >Citizens and economy<), see tweets 3 and 19. In the following tweet AfD's Federal spokesman Jörg Meuthen is referring to Merkel and Söder as agents of a >disaster< leading to the >Mass death of companies :

(4) Prof. Dr. @ Joerg_Meuthen betonte gegenüber der JF, \#Merkel und \#Söder scheine »in keiner Weise klar zu sein, was für ein Desaster sie derzeit anrichten«. Falls der \#Lockdown bis Ostern verlängert werde, führe das zu einem Massensterben von Unternehmen. https://t.co/IzrwqpAeYS (tweet 9).

In the example (4) it is also alleged that Merkel and Söder are not aware of the consequences of their actions - a claim that tackles their competence even more. The (de-)legitimation strategy used by Meuthen is a reference to a moral evaluation that consists in capitalistic values of economic growth - a common argumentation scheme of the AfD.

The performance of Merkel, Spahn (CDU), Federal Minister of Health, and other ministers is attacked not only when it comes to their competence but also regarding fairness and commitment as the other two criteria of this component of trustworthiness. The following tweet combines all three criteria with the claim that Merkel and Spahn would >stir up fears in an irresponsible way> (fairness), would lack of $>$ reasonable concepts and a plan B> (competence) and asking suggestively if >the government does care about the people or only about gaining power for Spahn> (commitment - or goodwill in the Aristotelean terminology):

(5) RT @Tino_Chrupalla: Lockdown bis Weihnachten? Spahn und Merkel schüren unverantwortlich Ängste. Vernünftige Konzepte? Plan B?

Fehlanzeige! Liegt der Regierung das Volk am Herzen oder nur der Machtgewinn für Spahn mit dem 3. Bevölkerungsschutzgesetz? https://t.co/ hGSjTT4Dhp (tweet 22).

The claim that the crisis would be used for political reasons is repeated constantly by the AfD, also combined with a rather common allegation, that is, the government would spread chaos -another point of critique of its performance (see tweet 14). The lexeme chaos is used seven times in the tweets referring to the opening and closure of schools (Schulchaos) and the vaccination strategy (Impf-Chaos), also naming the government explicitly as the agent as in and \#GroKo-Impf-Chaos, Chaos-Regierung and Chaos-Verantwortliche \#Jens Spahn (tweets 33, 12, 16, 15). The federal and state governments' supposed lack of straightforwardness is also addressed by the composition \#Corona-Wirrwarr (Eng. >confusion, mess $>$ ) in tweet 31.

The federal government is labeled >the greatest danger of the \#Corona crisis>, threating >human live> and >the future> (tweets 25, 13), >destroying the economy and the society> (tweet 17) with its politics. The Minister-President of Bavaria, Markus Söder, is called a >danger for the inner peace of our country> (tweet 11), while Chan-

12 Ursula von der Leyen (CDU) is the President of the European Commission (2019-). 
cellor Angela Merkel is >becoming a risk> (tweet 39) and would >ruin our country and our society> (tweet 39) - the verb ruinieren (Eng. >to ruin >) is used four times, every time naming Merkel as the agent. The >topos of threat $>$ is addressed further by calling the government's politics >destructive> (tweet 20), claiming >the Merkel government is placing the axe on our national economy> (tweet 37). As the examples show, the AfD uses the $>$ (de-)legitimation by reference to evaluation $>$ excessively, considering >economic values decisive. Therefore, the personification of the economy is one rhetorical way to highlight its value as in a statement by Beatrix von Storch, Deputy Leader of the AfD, that is quoted in tweet 23, where it is claimed to be mortal: »We must protect human lives, but not let the economy die in the process! « (See also example 4 where the expression >Mass death of companies> is used).

\subsection{Bolsonaro's attacks on the trustworthiness of the media}

In Bolsonaro's corona discourse on Twitter (561 tweets and retweets on @jairbolsonaro) questions of trust, truth and disinformation are addressed directly. The term verdade (Eng. >truth $>$ ) is used ten times, indicating that there is wrong information circulating that is being corrected by the Brazilian President and his ministers, according to the motto $\gg \mathrm{A}$ HORA DA VERDADE« $(\text { Eng. >the hour of truth })^{13}$ (tweet 13). The supposedly wrong information concerns the corona crisis in general, the vaccinations, the medication, the auxiliary program, and corruption involving public money for the crisis response (tweets 22, 2, 18, 13/19, 5). Whereas Bolsonaro announces to >restore the truth about the vaccine in Brazil> and >other truths $>$ in his weekly live video (tweet 2) he blames the media indirectly to not telling the truth as to say to lie and to spread wrong information -, noting:

(6) Boa imprensa não é a que mais critica ou elogia, mas aquela que fala a verdade. Teremos a vacina de forma segura e eficiente, para todos os voluntários, depois de certificada pela @anvisa_oficial (tweet 1). ${ }^{14}$

In another tweet Bolsonaro gets explicit, when stating that $\gg \mathrm{C}[\mathrm{c}]$ ontrary to what the Brazilian media reported «

(7) [...] a retirada do status de »uso emergencial hospitalar« pela FDA na verdade AMPLIA o tratamento com hidroxicloroquina nos EUA, permitindo o uso do medicamento, antes restrito, em qualquer ambiente, desde que receitado por um médico (tweet 18). ${ }^{15}$

While disregarding the health experts' recommendations, Bolsonaro himself continuously gives advice on how to treat or avoid an infection with COVID-19 as can be seen in the example (7). During the first six month of the pandemic Bolsonaro

\footnotetext{
13 All translations of Bolsonaros's tweets are mine. The complete Portuguese wording can be found in the appendix (table 5), followed by the corresponding Twitter-ID.

14 Eng. >Good press is not the one that criticizes or praises the most, but the one that tells the truth. We will have the vaccine, safe and efficient, for all volunteers, after certification by @ anvisa_oficial.<.

15 Eng. >[...] the removal of the status 'hospital emergency use' by the FDA actually EXTENDS hydroxychloroquine treatment in the US by allowing the previously restricted use of the drug in any setting, as long as it is prescribed by a doctor.<.
} 
recommends strongly the use of hydroxychloroquine, a medication used as a treatment for malaria and rheumatoid arthritis. As studies show, it does not bring any clinical benefit in patients with COVID-19 (cf. University of Oxford 2020) but can cause heart rhythm problems and serious side effects. The Food and Drug Administration, FDA (2020), »cautions against use of hydroxychloroquine or chloroquine for COVID-19 outside of the hospital setting or a clinical trial.«Bolsonaro continues to recommend its use anyways and dismisses the results as misrepresentation by the media:

(8) No mais, essa mesma rede de TV desdenhou, debochou e desestimu-

lou o uso da Hidroxicloroquina que, mesmo não tendo ainda comprovação científica, salvou a minha vida e, como relatos, a de milhares de brasileiros (tweet 8). ${ }^{16}$

In the cited tweet (8) Bolsonaro refers to his own positive experiences with the use of hydroxychloroquine (legitimation by personal authority), exaggerating, it would have saved his life, and - limiting the certainty of his statement with a vague formulation - that of »thousands of Brazilians«. The observation that »even though it has no scientific proof yet « gives an indication of the little weight Bolsonaro gives to scientific findings, while referring to himself as a positive example is a common strategy in his rhetoric. In another tweet about the use of hydroxychloroquine in case of an infection Bolsonaro refers vaguely to »those who argue against Hydroxychloroquine, but don't present any alternatives, I regret to inform you that I am very well with its use and, with the grace of God, I will live for a long time to come « (tweet 15). In one of the last statements on the subject on Twitter that dates to September 23, 2020, the president refers to the director of a hospital in Barretos, state of São Paulo, who »recommends Chloroquine for the treatment of Covid-19« (tweet 6). This authority (strategy of legitimation by reference to expert authority) begins his statement in the video that is linked by Bolsonaro as follows: »I'm not a doctor, but I'm the son of a doctor «. He then praises the »fantastic effect $«$ of hydroxychloroquine. Bolsonaro considers the dismissal of the medicine as a matter of politization against him. He retweets a user's thesis that »If Bolsonaro or Trump said that Chloroquine is bad for you, the media would support Chloroquine. If they said that oxygen is good for you, they would tell you to hold your breath« (tweet 23). Bolsonaro himself characterizes »most of the media >Near the President the bloggers wear masks so they can attack him, but when they move away, they take them off « (tweet 30). In the attached video that is supposed to prove his point, three people take off their masks after leaving a crowd. Therefore, in this tweet a single case is used to legitimize a general assumption: That the media is lacking straightforwardness.

Bolsonaro uses Trump's expression fake news on a regular basis, equating it with a lie: Mais uma mentira (FAKE NEWS) (Eng. >Another lie<). ${ }^{17}$ On Twitter it

\footnotetext{
${ }^{16}$ Eng. >Moreover, this same TV network disdained, debauched and discouraged the use of hydroxychloroquine that, even without scientific proof, saved my life and, as reported, that of thousands of Brazilians.<.

17 This tweet is not part of the corona discourse, it can be accessed through https://twitter.com/ jairbolsonaro/status/1314290803712368640 (22.06.2021).
} 
appears twice in the corona discourse and four more times in other contexts. There is no explicit naming of the agent for this type of information when referring to interims Minister of Health, Eduardo Pazuello, a Brazilian Divisional general who is supposed to »clear some points « without »distortions or fake news « (tweet 14). The verb esclarecer (Eng. >to clear $<$ ) is used five times, not specificizing who is supposed to disseminate wrong information as shown in the following example:

(9) Esclarecemos que a referida MP, ao contrário do que espalham, resguarda ajuda possível para os empregados. Ao invés de serem demitidos, o governo entra com ajuda nos próximos 4 meses, até a volta normal das atividades do estabelecimento, sem que exista a demissão do empregado (tweet 27). ${ }^{18}$

Instead, Bolsonaro could not be more explicit on whom to blame for spreading wrong information, when urging his readers not to believe in the media:

\section{(10) NÃO ACREDITE NA MÍDIA FAKE NEWS! SÃO ELES QUE PRECISAM DE VOCÊS! (tweet 29). ${ }^{19}$}

Moreover, Bolsonaro uses the word mentira (Eng. >lie $<$ ) two times when referring to the media in the corona discourse, once with reference to »many in the press « as in »as mentiras de muitos da imprensa « (Eng. >the lies of many of the press $<$ ) (tweet 3) and in the second example being the one who is »disproving lies from the press « (»Desmentindo mentiras da imprensa «) (tweet 4). He also uses the verb mentir (Eng. >to lie $<$ ) one time, claiming that »a major part of the media « would lie $» 24$ hours a day« (tweet 21).

The term desinformação (Eng. >disinformation<) that is crucial in the infodemic is used three times by Bolsonaro, always without naming explicitly an agent that is to be held responsible. The president claims that »disinformation has been a widely used weapon« in two tweets with a similar wording on two consecutive days:

(11) - Na guerra ao vírus a desinformação foi uma arma largamente utilizada.

- O pânico foi disseminado fazendo as pessoas acreditarem que só tinham um grave problema para enfrentar (tweet 10). ${ }^{20}$

(12) D- A desinformação foi uma arma largamente utilizada. O pânico foi

disseminado fazendo as pessoas acreditarem que só tinham um grave problema para enfrentar.

- Não será fácil, mas havemos de recomeçar. BOM DIA A TODOS (tweet 11). ${ }^{21}$

\footnotetext{
18 Eng. > We clarify that the mentioned MP, contrary to what is being spread, provides potential support for the employees. Instead of being fired, the government will help them for the next 4 months, until the normal activities of the establishment are resumed, without dismissal of the employee.<.

19 Eng. >DON'T BELIEVE THE FAKE NEWS MEDIA! IT IS THEM THAT NEED YOU! .

20 Eng. >- In the war on the virus disinformation was a widely used weapon. - Panic was spread by making people believe that they only had one serious problem to face.<.

21 Eng. D- Misinformation was a widely used weapon. Panic was spread by making people believe that they only had one serious problem to face. - It won't be easy, but we will start over. GOOD MORNING TO ALL.
} 
As it is widely known that Bolsonaro alleges the media for »spreading panic « - another crucial predication concerning its trustworthiness regarding the criteria fairness and transparency - there is no need for an explicit reference. Additionally, it can be assumed that the effect for the creation of an overall climate of distrust might even be bigger when being vague about the agent. The analysis shows that Bolsonaro is using this kind of war rhetoric ${ }^{22}$ only a short period of time during the pandemic. This is somewhat plausible, as the Brazilian president downplays the threats of the pandemic. To portray the virus as an >evil enemy< against whom you must go to war would be contradictory in this respect. In the third tweet in which the term >disinformation< appears, Bolsonaro utilizes the rhetorical figure of a personification when claiming that it >kills even more than the virus itself $<$ :

(13) A desinformação mata mais até que o próprio vírus. O tempo e a ciência nos mostrarão que o uso político da Covid por essa TV trouxe-nos mortes que poderiam ter sido evitadas (tweet 9). ${ }^{23}$

As »this TV network « is being named in the following sentence the interference to the one being blamed for disinforming can easily be made. Besides the allegation of disseminating wrong information the claim that the media would use the pandemic for political reasons is undermining its credibility even further. It is somewhat unusual that Bolsonaro is appreciating the science in this example (13), because usually he discredits advice given by health experts during the pandemic. He calls measurements >extreme without planning and rationality< (tweet 26) and disregards them by not keeping distance himself, not wearing a mask and so on (cf. Leschzyk 2020). Bolsonaro claims that »the best cure « would be »to go back to work « (tweet 7), constantly referring to economic values to delegitimize the recommended actions. The president equates lives and jobs (tweet 16) and considers »the virus and unemployment « as »two problems that cannot be separated «, warning that »if the medicine is too much, the side effect will be much more disastrous« (tweet 24).

\section{Conclusion}

It is striking that in the corona infodemic misinformation and even conspiracy theories are often promoted by popular political actors, regardless of whether they are running the government or in the opposition. In Germany, the opposition party AfD focuses on blaming the government, which they hold responsible for what they name insane and a chaos. They call the government crazy and anti-democratic, even evoking a dictatorship. In summary the answer to the question »Why shouldn't we

\footnotetext{
22 The word weapon (Pt. arma) is used three times (tweets 10, 11, 17), the word war (Pt. guerra) four times (tweet 10, 12, 20, 28), for example, as in the following tweet 20: »DIA DO ENFERMEIRO - Na atual guerra que enfrentamos, existem aqueles que estão lutando na linha de frente pelas nossas vidas. - Nesta data, parabenizamos todos os enfermeiros do Brasil pelo seu dia.« (Eng. >NURSES<DAY - In the current war we are facing, there are those who are fighting in the frontline for our lives. - On this date, we congratulate all the nurses in Brazil for their day. $<$ ).

23 Eng. >Disinformation is more deadly than the virus itself. Time and science will show us that this TV's political use of Covid has brought us deaths that could have been avoided.<.
} 
trust the government in the corona crisis? « given by the AfD is: The governing politics are lacking competence and straightforwardness. They have no constitutional legitimation and do not act according to our economic values.

The Brazilian president on the other hand is aiming at the media's trustworthiness, also evoking an invisible actor with bad intentions as a scapegoat. He is attacking the media's credibility focusing on the criterion honesty, accusing them to lie, to spread fake news and disinformation. His references and attributions can also be considered an attack on the media's performance given the fact that the balanced information of the public is one of its main functions. Besides blaming the others Bolsonaro's communication centers on himself: He makes alternative recommendations like using hydroxychloroquine, a medication that can cause severe side effects and brings no benefit in patients with corona disease. He often does not give any justifications for his claims and is creating a general climate of distrust by not naming agents explicitly.

Having in mind the ancient Aristotelean criteria of »How to appear a credible person « - good sense, moral character, and goodwill - it can be summarized that the AfD concentrates on the first one (as to say the government's supposed lack of expertise), slightly touching goodwill when indicating that the governing politics do not care for the people, while Bolsonaro is focusing on the media's supposedly inherently poor character. Both parties - the AfD in Germany and Jair Bolsonaro in Brazil - are sowing doubt and distrust constantly. This strategy is not only making people, institutions and the media seem unreliable, it also relieves the speakers from providing references of legitimation for their own claims as someone who reveals $>$ the truth< is supposed to tell >the truth< himself.

In a pandemic it is crucial that scientifically proven recommendations reach the public. To do so, building trust in the institutions and in the media is key. For that reason, political communication should be clear, open, truthful, and up to date, as well as empathetic and consistent, so that trust can be gained, and measurements will be accepted. Nevertheless, at the end of the day, it is not enough to communicate that way - actions must be taken accordingly.

\section{Appendix}

\section{Cited tweets}

The following table contains tweets published via the accounts of @AfD and @jairbolsonaro. These can be viewed in full via the attached links, inserting https:// twi2tter.com/AfD/status/ respectively https://witter.com/jairbolsonaro/status/ beforehand (accessed on 11.03.2021). The highlighting in bold is mine. The listing is in reverse chronological order. 


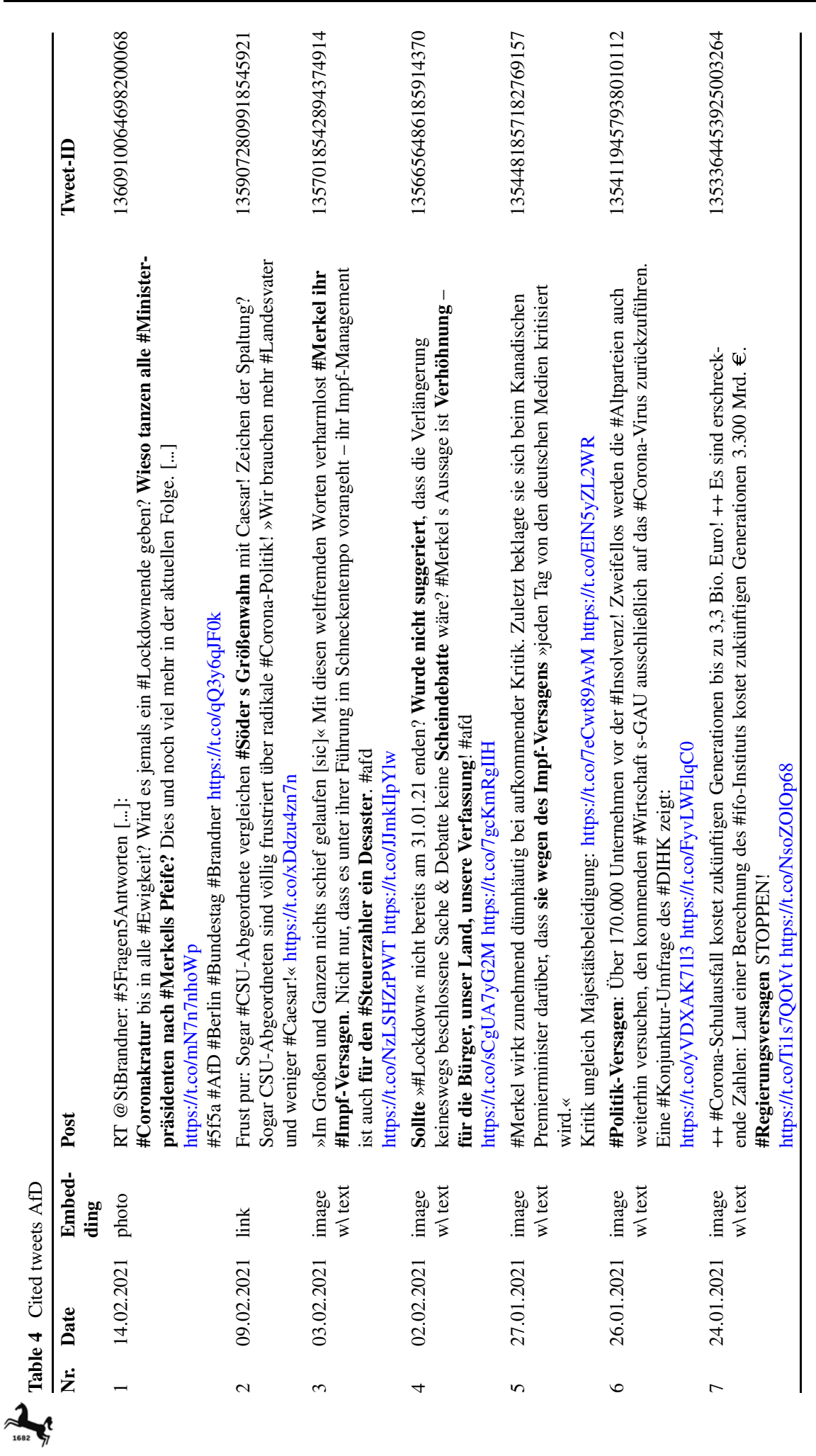




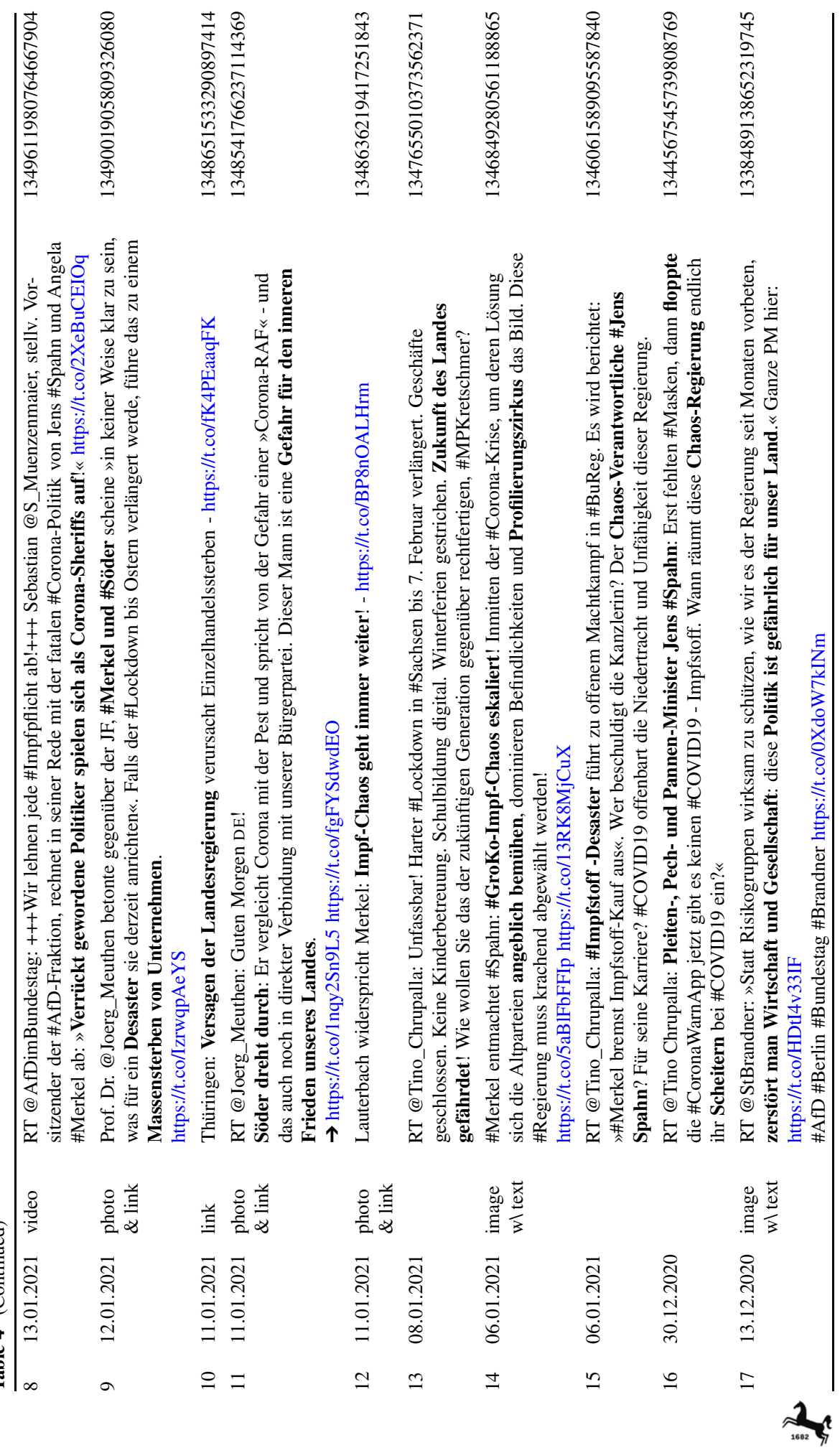




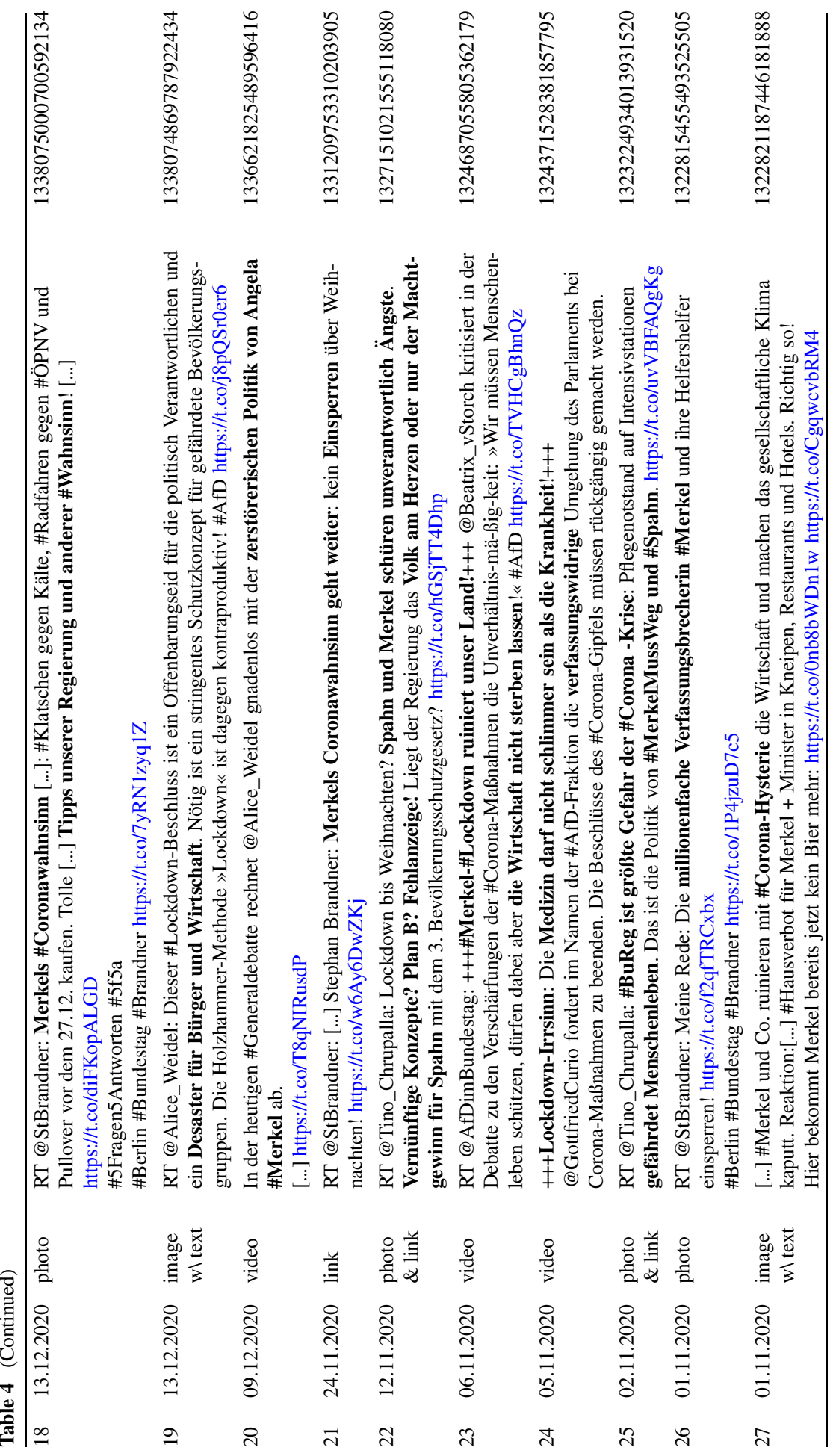




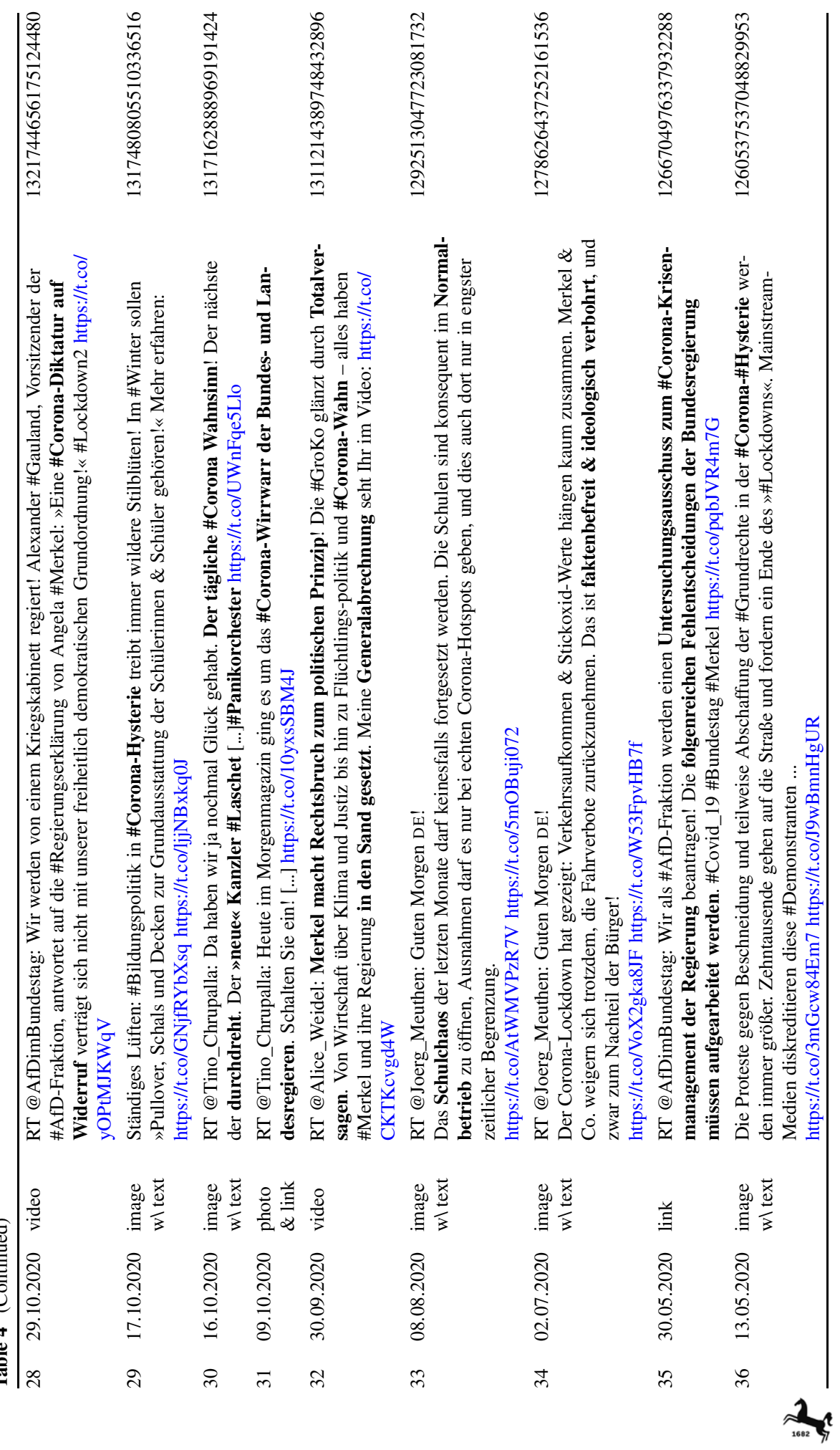




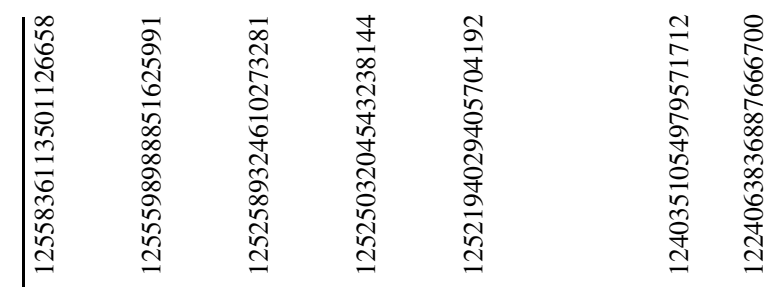

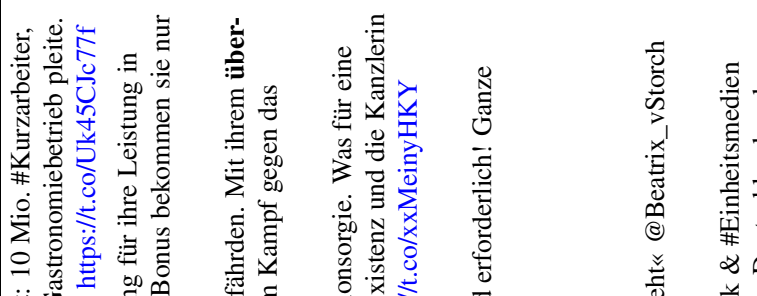

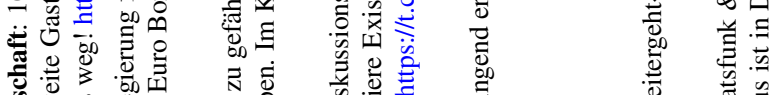

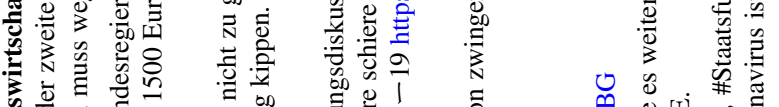

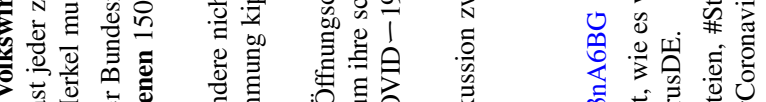

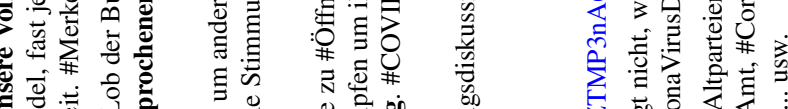

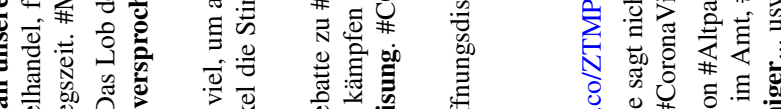

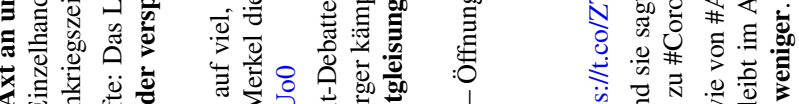

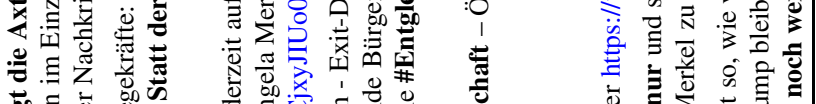

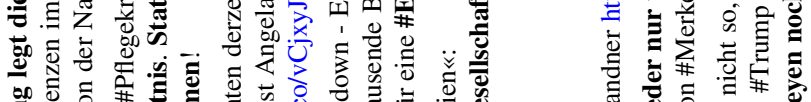

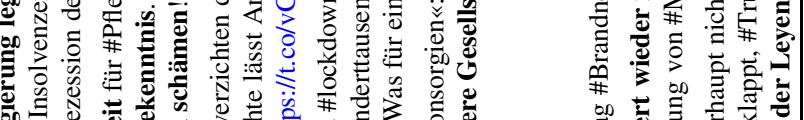

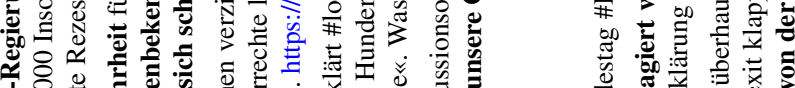

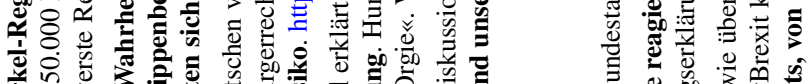

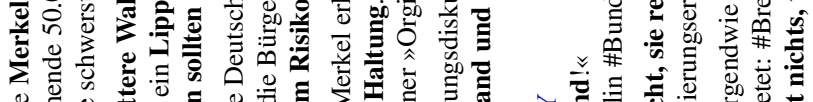

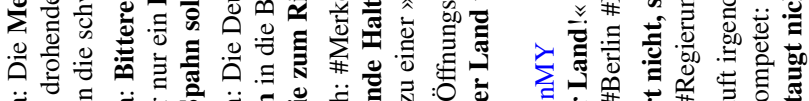

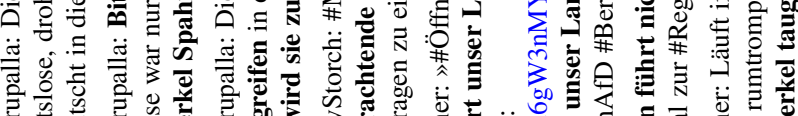

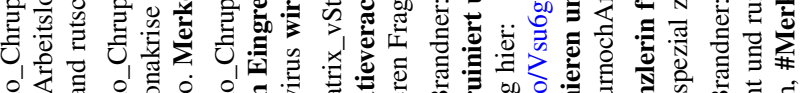

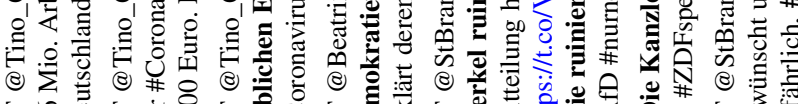

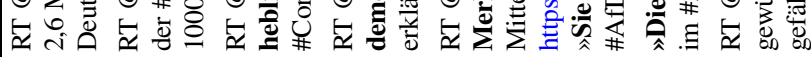

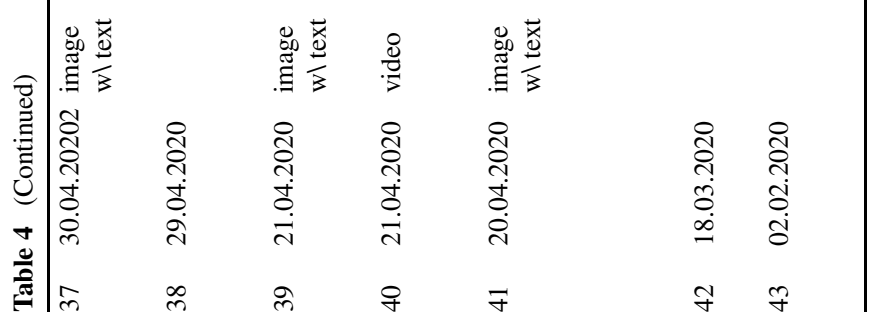




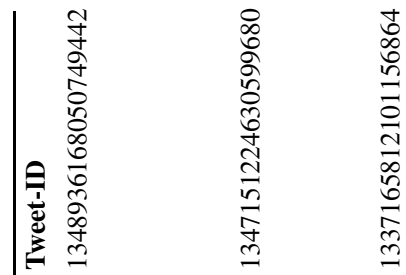

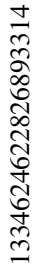

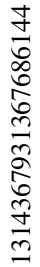

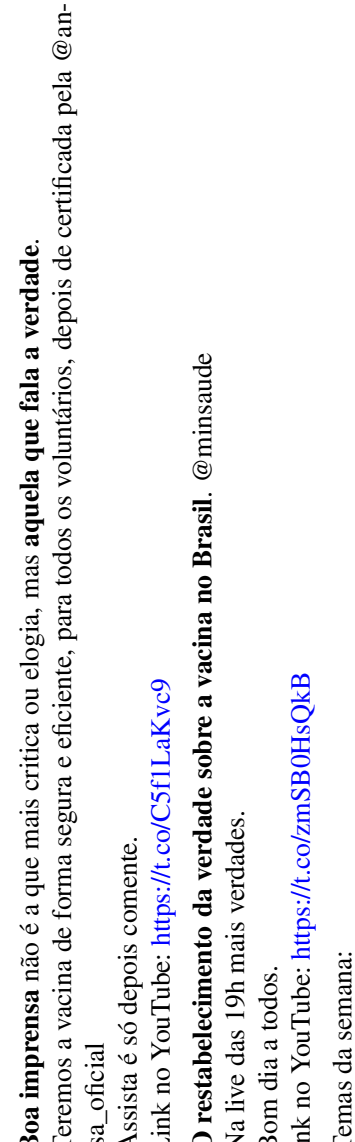

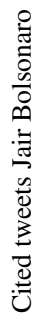
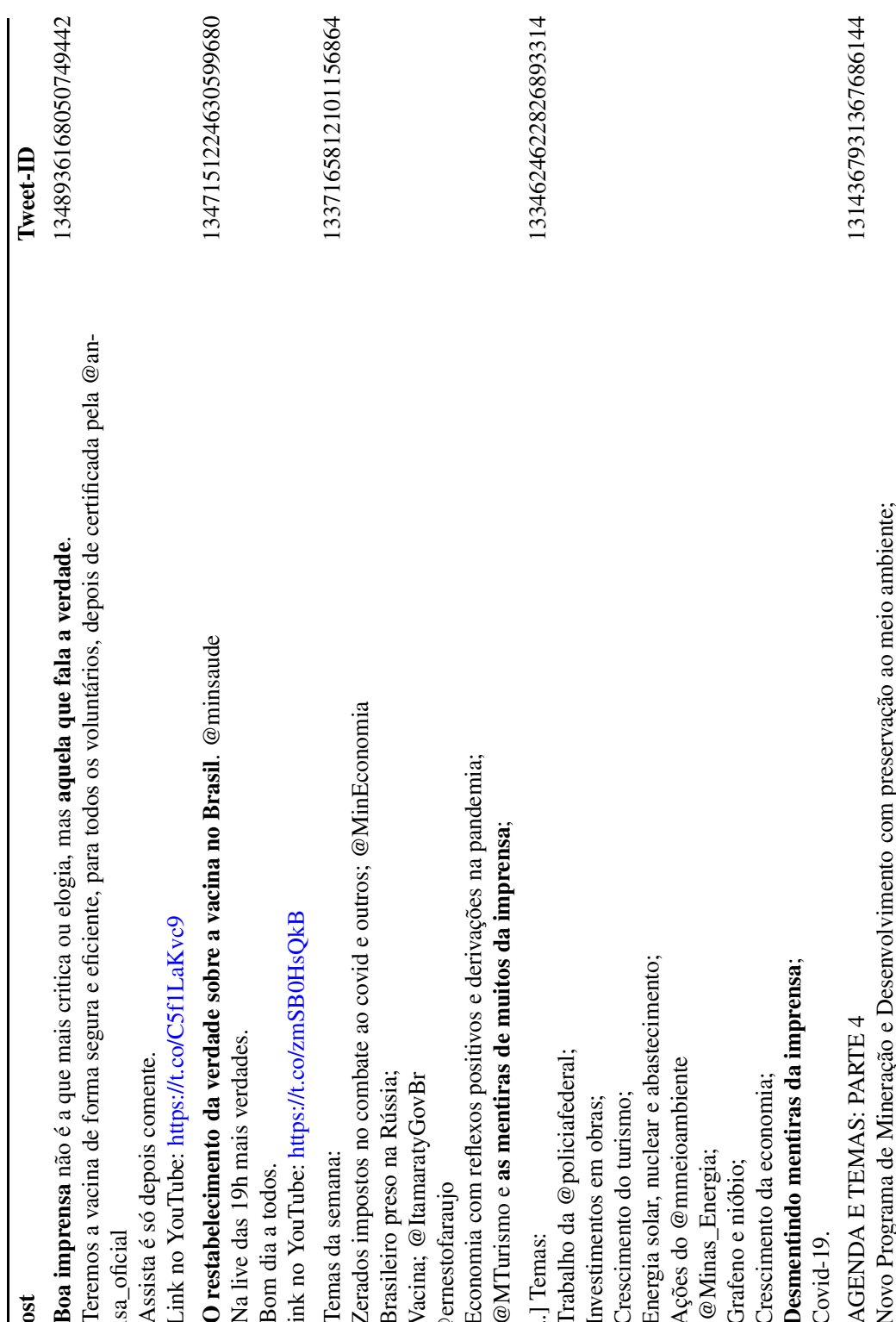

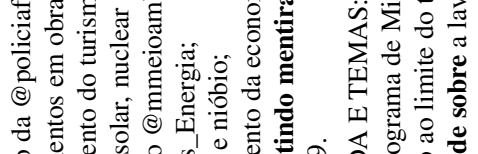

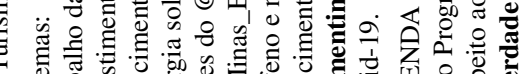

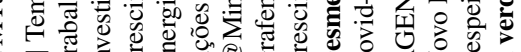

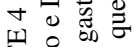
究密 纯

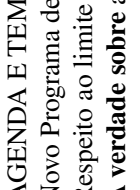

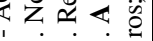
这 


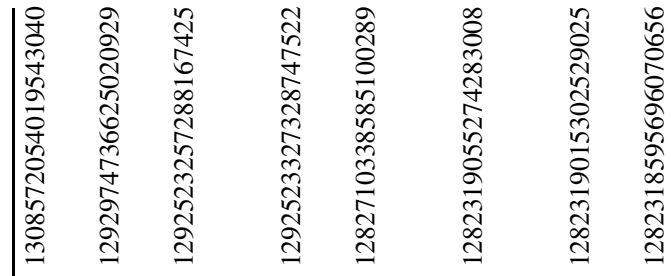

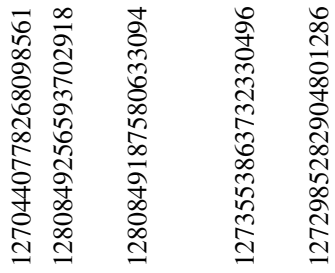

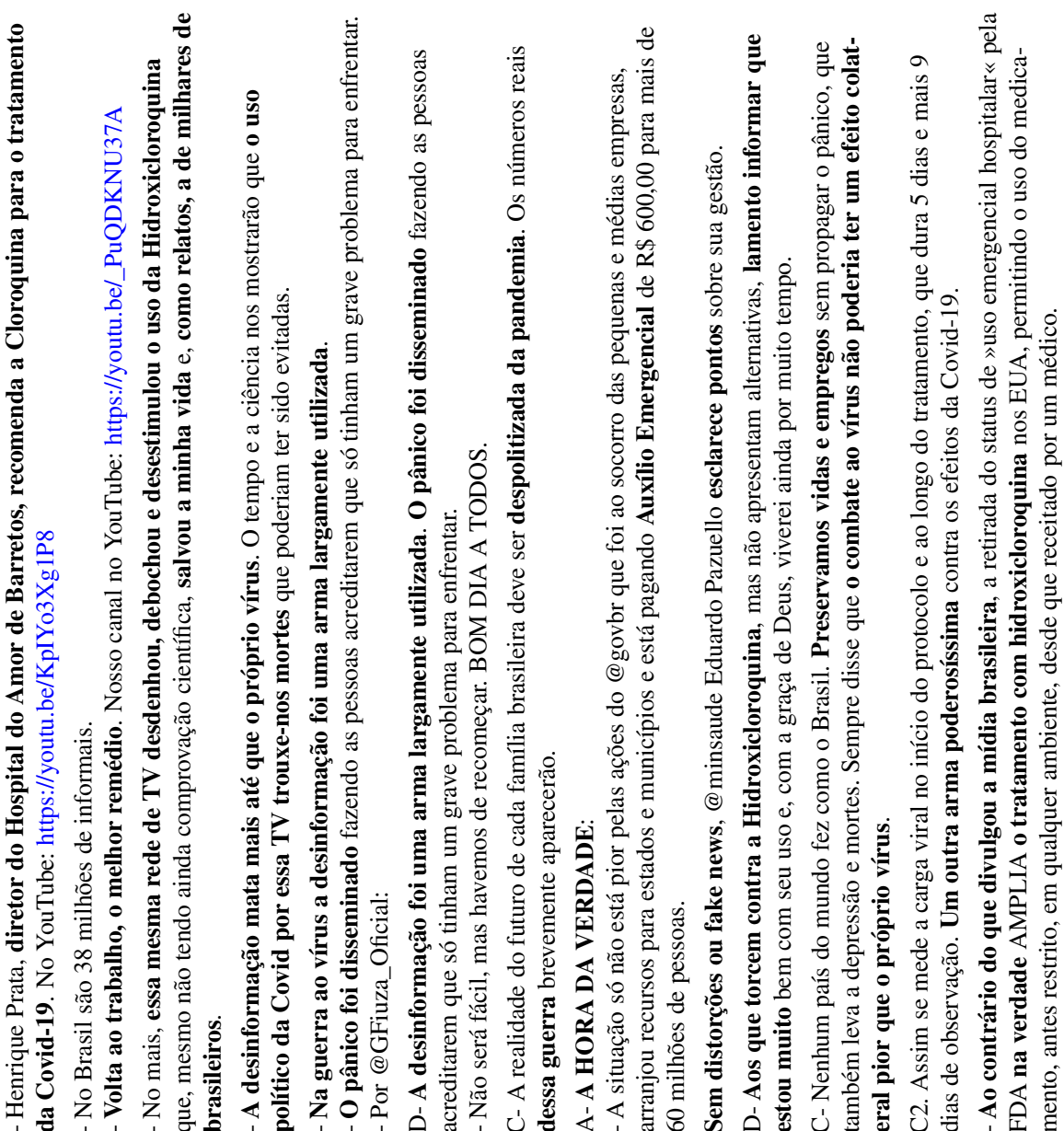

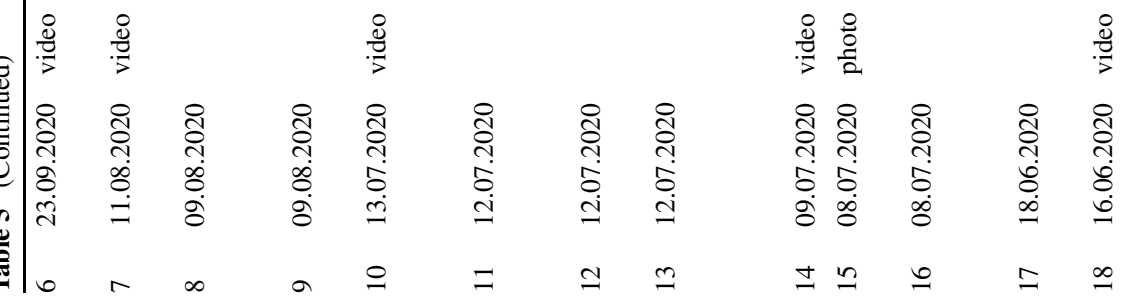




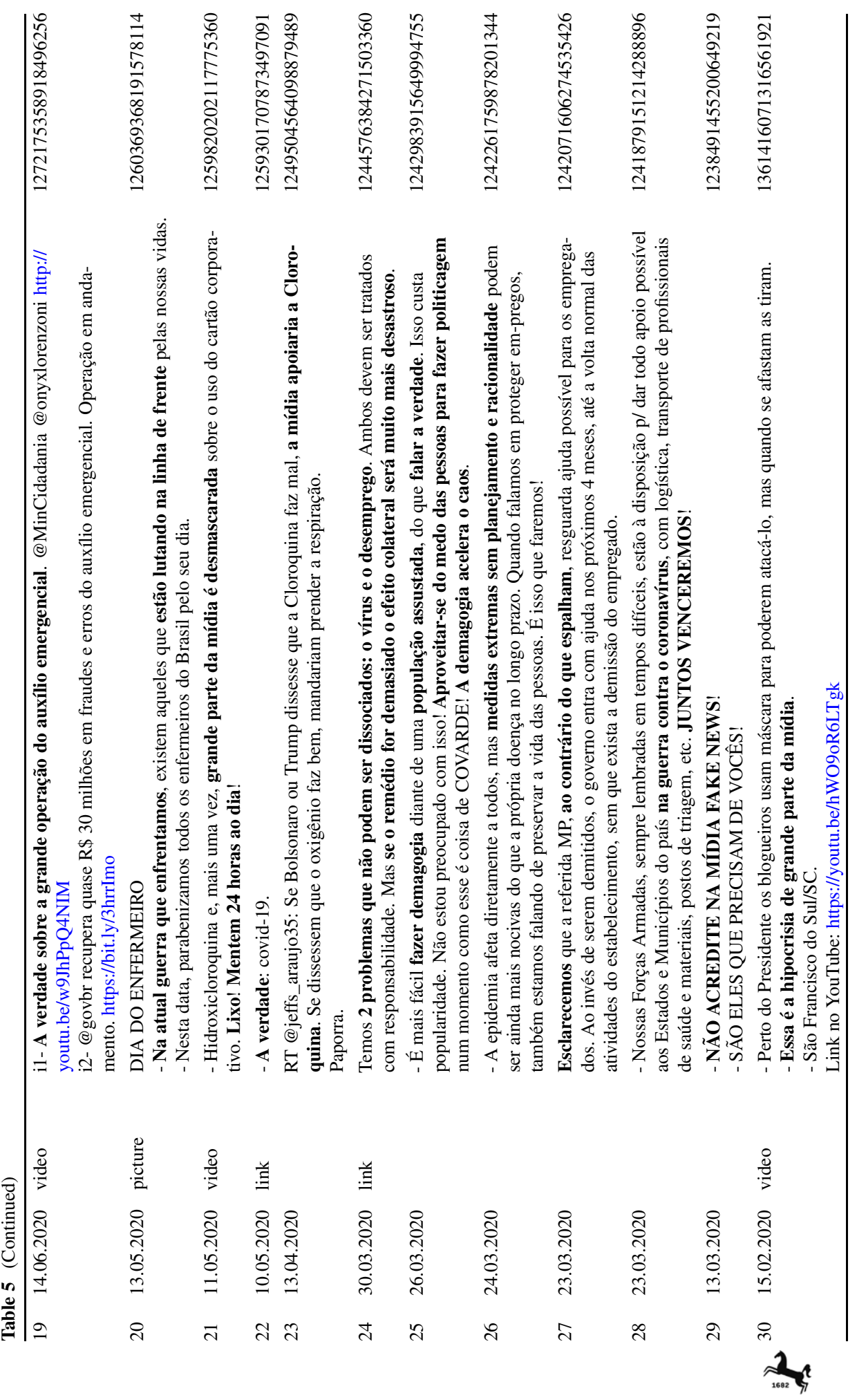


Funding Open Access funding enabled and organized by Projekt DEAL.

Open Access This article is licensed under a Creative Commons Attribution 4.0 International License, which permits use, sharing, adaptation, distribution and reproduction in any medium or format, as long as you give appropriate credit to the original author(s) and the source, provide a link to the Creative Commons licence, and indicate if changes were made. The images or other third party material in this article are included in the article's Creative Commons licence, unless indicated otherwise in a credit line to the material. If material is not included in the article's Creative Commons licence and your intended use is not permitted by statutory regulation or exceeds the permitted use, you will need to obtain permission directly from the copyright holder. To view a copy of this licence, visit http://creativecommons.org/licenses/by/4. $0 /$.

\section{References}

Ajzenman, Nicolás/Cavalcanti, Tiago/Da Mata, Daniel (2020): More Than Words: Leaders' Speech and Risky Behavior during a Pandemic. In: SSRN Electronic Journal 22.04.2020 [Preprint research paper].https://doi.org/10.2139/ssrn.3582908 (30.03.2021).

Alternative für Deutschland (2021): Startseite Homepage. In: www.afd.de (07.03.2021).

Amann, Melanie (2017): Angst für Deutschland. Die Wahrheit über die AfD: wo sie herkommt, wer sie führt, wohin sie steuert. München: Droemer.

Aristotle (2015): Rhetoric [350 BC]. [Translated by W. Rhys Roberts]. Fairhope: Mockingbird Classics Publishing.

Brennen, J. Scott et al. (2020): Types, sources, and claims of COVID-19 misinformation. In: https:// reutersinstitute.politics.ox.ac.uk/types-sources-and-claims-covid-19-misinformation (26.07.2021)

Butter, Michael (2018): »Nichts ist, wie es scheint«. Über Verschwörungstheorien. Bonn: Suhrkamp.

Cambridge Dictionary (2014): Credibility. In: https://dictionary.cambridge.org/de/worterbuch/englisch/ credibility (07.03.2021).

Collins Dictionary (n.d.): Credibility. In: www.collinsdictionary.com/de/worterbuch/englisch/credibility (07.03.2021).

Câmara dos Deputados (2019): Biografia do Deputado Federal Jair Bolsonaro. In: www.camara.leg.br/ deputados/74847/biografia (19.07.2019).

Decker, Frank (2004): Der neue Rechtspopulismus. Opladen: Leske und Budrich.

Decker, Frank/Ruhose, Fedor (2021): Brennglas Pandemie: Wie die Coronakrise Eigenheiten und Schwächen unseres Regierungssystems bloßlegt: Fachinformationsdienst für internationale und interdisziplinäre Rechtsforschung. In: https://verfassungsblog.de/brennglas-pandemie (30.03.2021).

Editorial Board (2020): The self-destruction of the >Tropical Trump $<$. Brazil's Jair Bolsonaro is building the case for his own impeachment. In: www.ft.com/content/72bed346-888b-11ea-9dcb-fe6871f4145a (05.07.2020).

FDA - Food and Drug Administration (2020): FDA cautions against use of hydroxychloroquine or chloroquine for COVID-19 outside of the hospital setting or a clinical trial due to risk of heart rhythm problems. 15.06.2020. In: www.fda.gov/drugs/drug-safety-and-availability/fda-cautions-againstuse-hydroxychloroquine-or-chloroquine-covid-19-outside-hospital-setting-or (30.03.2021).

Ghebreyesus, Tedros Adhanom (2020): Director-General's remarks at the media briefing on 2019 novel coronavirus on 8 February 2020. In: www.who.int/director-general/speeches/detail/director-generals-remarks-at-the-media-briefing-on-2019-novel-coronavirus---8-february-2020 (31.03.2021).

IfD Allensbach (2021): Zweitstimmen-Wahlabsicht. In: www.ifd-allensbach.de/studien-und-berichte/ sonntagsfrage/gesamt.html (07.03.2021).

JHU (2021): COVID-19 Dashboard by the Center for Systems Science and Engineering (CSSE) at Johns Hopkins University (JHU). In: https://coronavirus.jhu.edu/map.html (21.06.2021).

Jörke, Dirk/Selk, Veith (2017): Theorien des Populismus zur Einführung (=Zur Einführung). Hamburg: Junius.

Köcher, Renate (2016): Die AfD - Außenseiter mit Rückhalt. Die Flüchtlingskrise hat der AfD eine Renaissance beschert. Sie ist auch die Partei gegen Europa und gegen die Globalisierung. In: Außenseiter mit beträchtlichem Rückhalt. Eine Dokumentation des Beitrags von Prof. Dr. Renate Köcher in der Frankfurter Allgemeinen Zeitung, Nr. 245, 20.10.2016, Institut für Demoskopie Allensbach. www.ifd-allensbach.de/fileadmin/kurzberichte_dokumentationen/FAZ_Oktober_2016.pdf (27.10.2020) 
van Leeuwen, Theo (1996): The Grammar of Legitimation. Unpublished manuscript.

van Leeuwen, Theo (2013): Legitimation in Discourse and Communication. In: Ruth Wodak (Ed.): Critical Discourse Analysis. Volume I. Concepts, History, Theory. London: Sage, pp. 327-349.

van Leeuwen, Theo/Wodak, Ruth (1999): Legitimizing Immigration Control: A Discourse-Historical Analysis. In: Discourse Studies, 1/1, pp. 83-118.

Leschzyk, Dinah (2020): Corona-Kommunikation. Wie Jair Bolsonaro die Wissenschaft diskreditiert und Verschwörungstheorien befeuert. In: promptus - Würzburger Beiträge zur Romanistik, 6, pp. 107-130.

Limaye, Rupali Jayant et al. (2020): Building trust while influencing online COVID-19 content in the social media world. In: The Lancet Digital Health, 6/2, pp. 277-278.

Longman Dictionary (2020): Credibility. In: www.ldoceonline.com/dictionary/credibility (07.03.2021).

Milbradt, Björn (2018): Über Autoritäre Haltungen in >postfaktischen Z Zeiten. Leverkusen-Opladen: Barbara Budrich-Esser.

Mudde, Cas/Rovira Kaltwasser, Cristóbal (2017): Populism. A very short introduction (=Very short introductions 510). Oxford, New York, NY: Oxford University Press.

Müller, Jan-Werner (2017): Was ist Populismus? Ein Essay. Berlin: Suhrkamp.

Odenbach, Marlene (2005): Glaubwürdigkeit in der PR: In Jahren erarbeitet, in Sekunden zerstört: Fünf Thesen aus der Sicht eines PR-Praktikers. In: Beatrice Dernbach/Michael Meyer (Eds.): Vertrauen und Glaubwürdigkeit: Interdisziplinäre Perspektiven, pp. 194-213. Wiesbaden: VS.

Oliveira Sargentini, Vanice Maria/Chiari, Geovana (2019): Mentirosos, corruptos e comunistas! As Fake News e o politicamente incorreto. In: Discurso \& Sociedad, 13(3), pp. 449-467.

Reisigl, Martin (2017): Sprachwissenschaftliche Diskriminierungsforschung. In: Albert Scherr/Aladin ElMafaalani/Emine G. Yüksel (Eds.): Handbuch Diskriminierung (=Springer Reference Sozialwissenschaften). Wiesbaden: Springer VS, pp. 81-100.

Reisigl, Martin/Wodak, Ruth (2001): Discourse and discrimination. Rhetorics of Racism and Antisemitism. London/New York: Routledge.

Renn, Ortwin (2019): Gefühlte Wahrheiten. Orientierung in Zeiten postfaktischer Verunsicherung. Leverkusen: Barbara Budrich.

Renn, Ortwin/Levine, Debra (1991): Credibility and trust in risk communication. In: Roger E. Kasperson/ Pieter Jan M. Stallen (Eds.): Communicating Risks to the Public. International Perspectives: Kluwer Academic Publishers, pp. 175-208.

Ribeiro, Amanda/Cunha, Ana Rita (2020): Bolsonaro deu 653 declarações falsas ou distorcidas sobre Covid-19 em seis meses de pandemia. In: www.aosfatos.org/noticias/bolsonaro-deu-656declaracoes-falsas-ou-distorcidas-sobre-covid-19-em-seis-meses-de-pandemia (27.10.2020).

Ruhose, Fedor (2020): Die AfD vor der Bundestagswahl 2021. Wirkung - Perspektiven - Strategien (=essentials). Wiesbaden: Springer VS.

Sieren, Frank (2020): Sieren's China: Coronavirus — an epidemic of rumors. In: www.dw.com/en/sierenschina-coronavirus-an-epidemic-of-rumors/a-52288831 (08.10.2020).

University of Oxford (2020): No clinical benefit from use of hydroxychloroquine in hospitalised patients with COVID-19. In: www.ox.ac.uk/news/2020-06-05-no-clinical-benefit-use-hydroxychloroquinehospitalised-patients-covid-19 (30.03.2021).

WHO et al. (2020): Managing the COVID-19 infodemic: Promoting healthy behaviours and mitigating the harm from misinformation and disinformation. In: www.who.int/news-room/detail/23-09-2020managing-the-covid-19-infodemic-promoting-healthy-behaviours-and-mitigating-the-harm-frommisinformation-and-disinformation (08.10.2020).

Williams, John T. (1985): Systemic Influences on Political Trust: The Importance of Perceived Institutional Performance. In: Political Methodology, 11 (1/2), pp. 125-142.

Wodak, Ruth (2015): The politics of fear. What right-wing populist discourses mean. London: Sage.

Xing, Xiaojing (2019): >Tropical Trump< doesn't faze Chinese firms. In: www.globaltimes.cn/content/ 1149252.shtml (05.07.2020). 